\title{
Canção Popular Versus Autoritarismo (Os Militares no Poder)
}

\author{
Pop Music vs Authoritarianism (Military Power)
}

\section{RESUMO}

A política nacional e a música popular brasileira sempre estiveram juntas. Desde a época do Estado Novo (1937-1945), com Getúlio Vargas, e até mesmo durante a Velha República, compositores e homens da administração pública, especialmente dos três poderes, vêm construindo a história do nosso país até nossos dias. Embora juntas, cada qual trilhou caminhos diferentes, em alguns momentos convergentes e noutros divergentes. Os políticos, em que pese todos os percalços e obstáculos inerentes ao jogo de interesses notórios nessa atividade, atravessaram décadas defendendo causas nobres e espúrias, democráticas e antidemocráticas. Durante muito tempo e ainda um pouco atualmente, a sociedade brasileira se vê surpreendida por falcatruas, corrupção e negociatas ilícitas, que colocam em risco os verdadeiros princípios republicanos da democracia no Brasil. O caso mais recente é chamado de "mensalão" pela mass media. Ao lado desse quadro, sabemos que nossa história está entrecortada de golpes contra presidentes legitimamente eleitos, reflexos da nossa frágil democracia. $\mathrm{O}$ último acontecimento sinistro dessa natureza se deu entre 1964 e 1985, com a presença dos militares, que fizeram suas leis e tomaram decisões à revelia da Constituição. A música popular brasileira participou deste episódio, contestando e denunciando por meio do discurso poético.

Palavras-chave: Canção. Militares. Autoritarismo. Censura. Democracia.

\section{ABSTRACT}

The national politics and the Brazilian pop music have always been united. Since the New State time (1937-1945) with Getúlio Vargas and even during the Old Republic, composers and men of public administration, especially from the three public powers, are building the history of our country until today. Even though together, each of them trod different paths. In some instances convergent but divergent at others. The politicians, in spite of all the setbacks and obstacles inherent in the game of interests notorious in this activity,

\section{Waldenyr Caldas}

Universidade de São Paulo. Escola de Comunicações e Artes, São Paulo, Brasil 
crossed decades championing noble causes and spurious ones, democratic goals and antidemocratic ones. For a long time and also a bit nowadays, the Brazilian society finds itself surprised by shenanigans, corruption and illicit negotiations, that endanger all the truly republican principles from democracy in Brazil. The most recent scandal is called mensalão by mass media. Alongside this, we know that our history is intersected of coups against legitimately elected presidents. The last of such a sinister event occurred between 1964 and 1985, with the presence of the military, which made up their laws and took decisions in defiance of the Constitution. Brazilian pop music actively participated of this episode, contesting and denouncing through its poetic discourse.

Keywords: Song. Militaries. Authoritarianism. Censorship. Democracy.

\section{INTRODUÇÃO}

\section{A música popular brasileira sempre acompanhou os acontecimentos políticos} do nosso país. Seja por meio da sátira, da denúncia, da mera narrativa dos fatos ou ainda em forma de protesto. Os elogios, a exaltação e o ufanismo, completam o quadro desse binômio música/política. Assim, através desses recursos, pode-se afirmar que é possível se conhecer muito bem a história política do Brasil ouvindo canções que tratam dos diversos momentos da nossa trajetória política.

Os exemplos são muitos e, para isso, vamos seguir a cronologia dos acontecimentos. Apenas como primeiro caso, comecemos pelo governo de Getúlio Vargas e, especialmente, pelo período histórico conhecido como "Estado Novo" (1937-1945). É dessa época o Departamento de Imprensa e Propaganda (DIP) que, entre outras coisas, servia como instrumento de censura do Estado. O rádio, principal veículo de comunicação da época, era estreitamente vigiado e controlado. Na prática, censurado pelo Governo Federal, atento a todas as formas de comunicação com a sociedade.

Na música popular, ou qualquer outra manifestação artística, a concepção do trabalhismo, de exaltação ao trabalho deveria estar presente. Mas não era assim que pensava uma parte dos compositores da canção popular desse período. Wilson Batista, por exemplo, sempre esteve na contramão do que desejava o Estado autoritário. Seu samba "Lenço no pescoço", feito dois anos antes da criação do Estado Novo, não exaltava o trabalhismo como queriam as autoridades. Ao contrário, a malandragem carioca é quem ganha o destaque e uma imagem bastante simpática no texto poético da canção. Versos e rimas como, "eu tenho orgulho em ser tão vadio", "eu vejo quem trabalha andar no miserê", "eu sou tão vadio porque tive inclinação", nos dão a ideia da transgressão daquele compositor. Mas, é bom que se diga: ele não estava só. Havia, nas mais diversas manifestações artísticas, uma atitude de resistência à política populista e autoritária implantada por Getúlio Vargas.

Com o fim do Estado Novo, o presidente Eurico Gaspar Dutra governaria o Brasil (1946-1951). Foi um governo que se propôs a redemocratizar o país, e não poderia ser de outra forma. Com desempenho sofrível, sua gestão seria ofuscada pela volta de Getúlio Vargas (1951-1954), mas, desta vez, eleito democraticamente. Agora, a canção popular volta mais forte à cena política do país. Os compositores Armando Cavalcanti e Klécius Caldas escreveram a marcha "Maria Candelária”, expressivo sucesso do carnaval de 
1952, que traz elementos da sátira, da denúncia e do próprio protesto. Tudo isso, claro, de forma muito bem humorada, quase um deboche, revelando-se um meio bastante inteligente de protesto contra os desmandos e a corrupção na administração pública.

Assim, passados 62 anos, o texto poético dessa marchinha carnavalesca continua atual. A personagem Maria Candelária representa a imagem do funcionário público oportunista e corrupto, como em nossos dias, que usufrui de privilégios escusos, como se nada estivesse acontecendo de grave com seu comportamento. Afinal, ela goza da proteção de político de prestígio e, entre outras coisas, recebe um salário e não trabalha. Mesmo assim, “caiu na letra ó, ó, ó, ó, ó!”, o que, na época, destacava os funcionários mais graduados, de funções mais relevantes e de melhores salários.

Mas, dos tempos de Maria Candelária até nossos dias, o Brasil mudou em muitos aspectos. Por uma questão de espaço, não podem ser discutidos aqui. Em um desses casos, porém, continuamos como há 62 anos atrás. A corrupção na administração pública, fez com que a personagem Maria Candelária atravessasse o tempo e passasse a conviver conosco no século XXI. A única diferença é que agora recebe o nome genérico de "funcionário fantasma". Como a personagem dos anos 1930, ele também ganha muito bem, tem proteção de político corrupto e não aparece para trabalhar. Apenas vai ao Banco no dia de pagamento receber seu salário.

Assim, apesar do sistemático uso da sátira, do protesto e da denúncia que se faz através da música popular brasileira, este vício espúrio permanece incólume, sem alteração na cultura política do nosso país. Não há dúvida de que, até mesmo em países onde a democracia já está consolidada, há casos de corrupção. Este exemplo, claro, não vale para o Brasil. Até porque, como todos sabemos, ainda não temos um processo democrático sólido, firme e consolidado. Em nossa trajetória política, podemos ver, pela canção popular, que as liberdades individuais nem sempre foram respeitadas. Em alguns momentos, a democracia foi arranhada, maltratada, até mesmo vilipendiada, para ceder espaço aos governantes autoritários.

Resta-nos um consolo. Sabermos, por exemplo, que a canção popular em todo esse período de autoritarismo, sempre criou resistência aos desmandos do Estado autoritário. Mas, infelizmente, sabemos que, em última instância, ele deixa resquícios e vícios abomináveis que se transferem para o Estado democrático. Um deles é a corrupção: em períodos de autoritarismo, os políticos não dão qualquer satisfação à sociedade sobre as finanças e muito menos sobre a governança do Estado; o desdobramento disso não é outro senão o aperfeiçoamento da corrupção, do oportunismo e dos desmandos políticos.

Não podemos nos esquecer do governo de Juscelino Kubistchek. Apesar de legitimamente eleito, quase não tomou posse. Ele recebeu o país muito fragilizado democraticamente. Isto, porém, não impediu que repetisse alguns vícios inaceitáveis durante seu mandato, que são bem próprios dos desmandos autoritários. O cantor/compositor Juca Chaves, em sua canção "Presidente bossa-nova”, faz uma sátira precisa, inteligente e bem humorada dos exageros em regalias do presidente. Algumas estrofes como "Voar, voar, voar, voar / voar, voar pra bem distante, / até Versalhes onde duas mineirinhas valsinhas / dançam como debutantes, interessante! / Mandar parente a jato pro dentista”, revelam bem as extravagâncias de um presidente com o dinheiro público. Na verdade, em que pese as inumeráveis virtudes do seu governo, este comportamento era uma 
herança do autoritarismo que tomou conta da política brasileira por muito tempo. Insisto em dizer que, apesar de vivermos em uma democracia à procura de sua consolidação, ainda temos políticos oportunistas que criam privilégios para si mesmos em detrimento dos cofres públicos e, por extensão, da própria sociedade. Este é o chamado crime de peculato, conhecido popularmente como "mordomia" com o dinheiro público.

O presidente, como chefe do poder executivo, podia tudo. Ou, quase tudo e, praticamente, não havia contestação a não ser em forma de paródia, sátira, denúncia ou protesto por meio da canção popular. Este é, aliás, um dos motivos fundamentais pelos quais nossa democracia sempre foi tão frágil. Sempre houve, pelo menos até o governo João Goulart, certo descompasso de ideias e objetivos entre os três poderes - especialmente entre o Legislativo e o Executivo. Enfim, são imperfeições do sistema presidencialista.

Entre outros motivos, essa fragilidade democrática, causada justamente por esse descompasso, facilitou o fatídico golpe militar de 31 de março de 1964. Aliás, mesmo antes da posse de João Goulart, já se vislumbrava a possibilidade de um golpe militar. Tanto é assim que, como Juscelino Kubistchek, João Goulart quase foi impedido pelos militares de assumir a presidência, em face da renúncia de Jânio Quadros.

Até aquele momento, ainda tínhamos uma débil democracia. Fraca, muito fraca. Após a deposição de Goulart, porém, passaríamos a conviver com o mais longo e cruel período na nossa história política. Foram 21 anos de autoritarismo militar no poder entre 31 de março de 1964 e 15 de março de 1985. Entre tantas formas de luta contra os desmandos e as arbitrariedades dos militares, deve-se enfatizar a importância da música popular brasileira.

\section{DISCUSSÃO}

Em 13 de dezembro de 1968 o governo Costa e Silva instaura o AI-5 e, assim, todos os veículos de comunicação passariam a ser severamente censurados. Era o fim da liberdade de imprensa. Mesmo assim, a resistência às arbitrariedades do Estado se fazia presente, às vezes de forma velada, outras vezes explicitamente. Na canção popular, por exemplo, os compositores usavam muito o recurso do duplo sentido nas letras de suas canções. Havia um jogo linguístico, metafórico e poético que o ouvinte deveria interpretar para, enfim, entender as intenções e a mensagem do autor.

É justamente nesse momento que a chamada canção de protesto reage mais intensamente às arbitrariedades do Estado autoritário. Ela assume o papel de resistência contra todas as formas de autoritarismo dos militares, como se fosse porta-voz da vontade da sociedade. Há um grande repertório dessas canções. Elas abordam os mais diversos temas como: censura, liberdades democráticas, tortura, desencanto com o país, revolução socialista, expectativa de dias melhores, imperialismo, pobreza, entre tantos outros. Mas é para apenas um aspecto que todos eles convergem: o desejo soberano de ver justiça social e liberdade democrática.

Duas canções tornaram-se, especialmente, referências nesse sentido. Elas trazem um texto poético velado e explícito. São elas, respectivamente, "Apesar de você”, de Chico Buarque, feita em 1970, e "Pra não dizer que não falei das flores”, de Geraldo Vandré, composta em 1968, quando a apresentou no Festival Internacional da Canção no Rio 
de Janeiro, no Ginásio do Maracanãzinho. Em sua canção, Chico Buarque faz um sutil exercício de linguagem e poesia para não demonstrar ao censor seus objetivos. Com raro talento, ele dissimula seus versos, justamente para driblar a censura. Em alguns casos, conseguiu, e noutras ocasiões, foi punido. De qualquer forma, essa punição viria mais cedo ou mais tarde, em função das arbitrariedades e dos desmandos militares.

Ao contrário do que já se veiculou em diferentes ocasiões pelos mass media e mesmo em ensaios acadêmicos, o autor de "A banda" e "Roda viva" não teve, em momento algum, a intenção de dirigir sua canção "Apesar de você" à pessoa do então presidente Emílio Garrastazu Médici*. E isso não teria nenhum sentido mesmo. Chico Buarque estava pensando, isto sim, na sociedade brasileira que vivia as agruras de uma ditadura terrível e sem qualquer perspectiva de redemocratizar-se.

Não por acaso, após tantas vezes proibido e intimado a prestar depoimento aos censores, o autor decidiu se autoexilar em Roma, entre os anos de 1969 e 1970, quando, afinal, pôde livremente fazer canções que permanecerão sempre em evidência no cancioneiro popular brasileiro. "Samba de Orly" é uma delas. Aquela situação era angustiante para as pessoas que sempre defenderam a liberdade. Em síntese, vivíamos uma tragédia. A censura, as prisões arbitrárias, o fechamento do Congresso Nacional, a cassação de mandato dos políticos legitimamente eleitos, mas que contestavam a ditadura, as torturas e os assassinatos de opositores do regime, são apenas algumas das sinistras condições a que foi submetida a sociedade brasileira nesse período.

Pela importância histórica que adquiriu essa canção, mas também para melhor compreendermos o momento político do nosso país naquela época, vale à pena reproduzirmos alguns trechos do texto poético de "Apesar de você".

Vejamos:

Hoje você é quem manda

Falou, tá falado

Não tem discussão, não

A minha gente hoje anda

Falando de lado e olhando pro chão. Viu?

Pois bem, diante da imposição da força bélica, das baionetas empunhadas em público e da truculência militar em situações quase pueris, não havia alternativa. Lutar desarmado contra o autoritarismo terrorista do Estado era algo comparável à escolha pelo suicídio.

Restavam poucas alternativas. $\mathrm{E}$ a que se mostrava mais eficiente era mesmo o verbo, a palavra, como forma de denúncia da tragédia que vivíamos. Uma denúncia que, seguidas vezes, precisava usar de figuras de linguagem como metáforas e metonímias, por exemplo, justamente para driblar a censura implacável que os militares instalaram no país. Nos versos, "a minha gente hoje anda / falando de lado e olhando pro chão. Viu?”, temos a exata dimensão do grau de repressão e de abatimento moral aos quais foi submetida a sociedade brasileira.

É difícil imaginar, mas não há nada mais humilhante do que ter de falar de lado olhando para o chão. Esta situação só se pode entender realmente quando vivida na prática. $\mathrm{O}$ esforço do poeta, no entanto, nos leva à realidade dos fatos.

Rev. Cult. Ext. USP, São Paulo, n. 10, p.29-40, nov. 2013
*Esta é a declaração de Chico Buarque sobre a canção "Apesar de você": "Faço menos músicas dedicadas às pessoas do que as pessoas pensam. Falaram que 'Apesar de você' era endereçada ao Médici, quando dizia respeito à situação do país como um todo". Entrevista concedida ao jornalista José Rezende Júnior, do Jornal Correio Braziliense em 2 de setembro de 1999. 
Figura 1 - Foto publicada no jornal Estado de S. Paulo sobre manifestação contra a ditadura militar. Disponível em: $<$ http://integras.blogspot. com.br/2008/12/h-40-anos-militares-assassinavam.html>. Acesso em: 15 set. 2013.

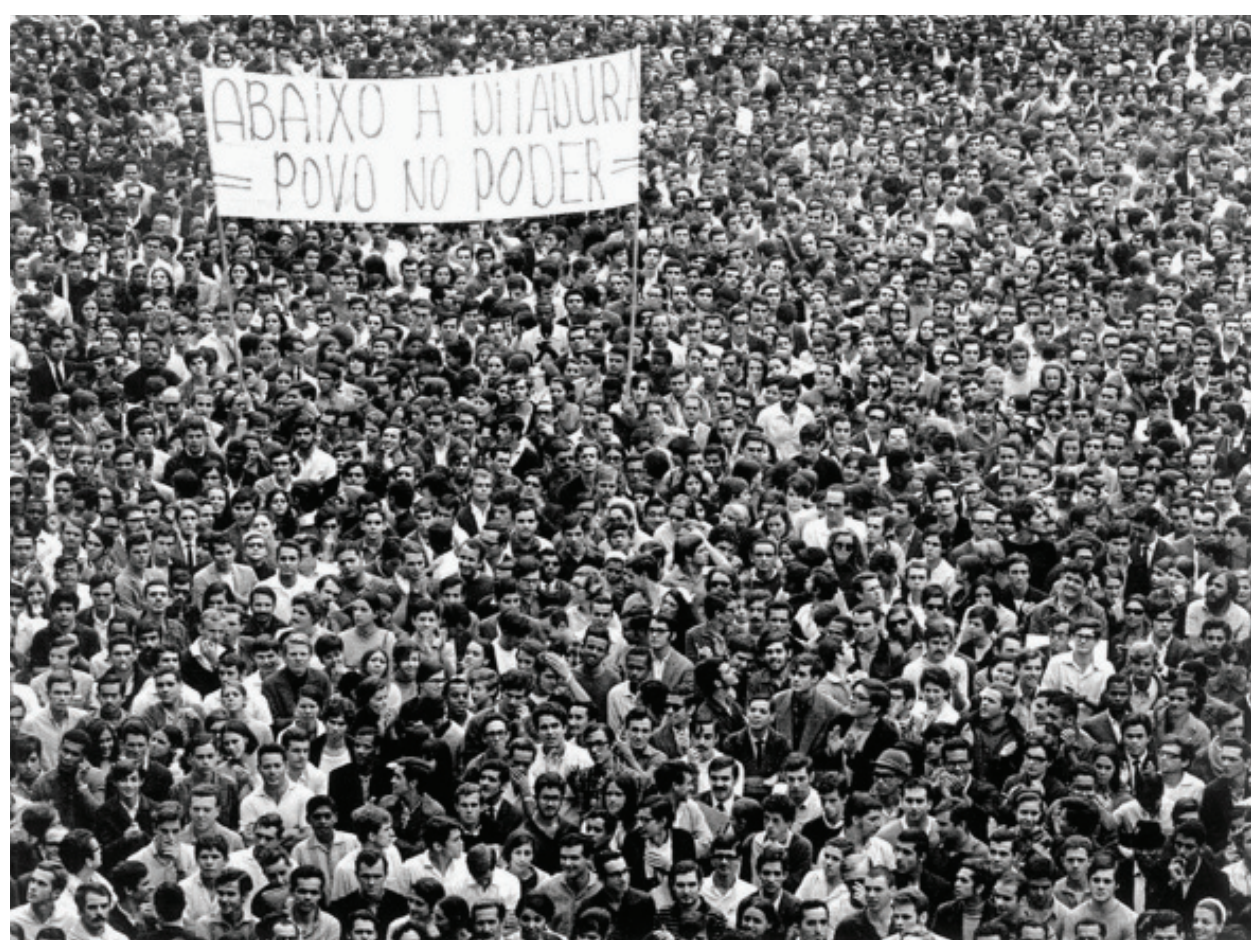

Ao longo dos versos de "Apesar de você" o que se percebe, entre outras coisas, é um justo desabafo do autor já asfixiado pela privação total de liberdade. Não bastasse esse aspecto, o Serviço de Censura de Diversões Públicas estava sempre propenso a bater o indesejável carimbo "interditado" nas canções de Chico Buarque.

Foi esse o principal motivo que o levou a adotar, em algumas músicas, o pseudônimo de Julinho da Adelaide. Mas essa asfixia a que me refiro não se restringia aos artistas, estudantes, professores, profissionais liberais e jornalistas, entre outros. $\mathrm{O}$ trabalhador das fábricas, dos escritórios, o transeunte das ruas, também sentiam o peso da repressão e da falta de liberdade. Esse segmento social acima citado era apenas o mais pugnaz, o mais combativo. Não tinha medo do perigo. Enfrentava sempre as baionetas e a tirania dos militares. Era um grupo em que seus partícipes corriam mais riscos de serem presos, torturados e até assassinados, como ocorreu ao longo dos 21 anos de regime militar.

Que se pense, apenas como exemplo, no conhecido caso de Vladimir Herzog, diretor de jornalismo da TV Cultura. Ele foi torturado até a morte nas dependências do DOI-CODI em São Paulo. Como este ensaio tem limite de espaço, não poderei me alongar sobre este tema. De qualquer forma, registro aqui uma sugestão: especialmente sobre mortos e desaparecidos políticos no Brasil nessa época, convém ler o livro Reparação ou impunidade?, organizado por Janaína Teles e publicado pela Humanitas/FFLCH, em 2001.

No tocante à análise do texto poético da canção em pauta, há um bom número de trabalhos feitos sobre a obra musical de Chico Buarque. Alguns deles abordam o binômio literatura/política, outros tratam da análise literária do texto poético. Vale à pena conferir.

Apenas para registrar, esta é uma das canções mais ricas, mais consistentes em seu conteúdo, como forma de expressão sobre o autoritarismo dos militares em nosso país. 
Certa ocasião, em entrevista concedida ao jornal Correio Braziliense, o entrevistador perguntou a Chico Buarque sobre as chamadas "canções de protesto". A resposta foi a seguinte: "De protesto mesmo, eu fiz poucas, talvez uma meia dúzia. Sobre a realidade social, eu continuo fazendo, como 'Assentamento"”**. O autor estava se referindo, nesse caso, à canção que fez sobre o Movimento Sem Terra.

Seja como for, o fato é que "Apesar de você" tem um forte discurso contestatório, que demonstrava, para a época em que foi composta, profunda angústia, tristeza e decepção com os rumos do nosso país. Ao mesmo tempo, ela nos traz a expectativa de que aquela tragédia decorrente da brutalidade dos militares não teria como permanecer. Em outros termos, é uma canção que inicia com mensagem extremamente forte da realidade sociopolítica brasileira e encerra seu discurso com um otimismo que renovava a energia das pessoas e das instituições que lutavam pela redemocratização do país. Basta analisar a história política do Brasil nessa época para concluir: Chico Buarque tinha razão, independentemente da beleza literária do seu texto poético.

A partir do governo do presidente Ernesto Geisel, as arbitrariedades dos truculentos militares foram diminuindo sensivelmente. $\mathrm{O}$ próprio presidente declarou que teríamos uma abertura política "lenta, gradual e segura". A ala mais radical, mais reacionária dos militares, bem que tentou impedir este projeto do presidente, mas esbarrou no seu prestígio e na liderança que ele tinha dentro das Forças Armadas. Para o bem do país, ele cumpriu seu projeto. Além disso, havia um grande clamor nacional pela redemocratização da nação, o que foi de grande importância política. Não poderíamos continuar asfixiados, calados, esperando os militares nos devolver o direito de participar politicamente das decisões do país.

Mesmo com toda a repressão do governo Médici, "Apesar de você” não foi imediatamente proibida. A censura não entendeu o texto poético de Chico e a liberou para divulgação em todos os mass media. Tanto é assim que, segundo a própria gravadora, a canção chegou a vender cerca de cem mil exemplares. Logo depois, no entanto, foi proibida e só liberada novamente em 1978.

A trajetória da canção "Pra não dizer que não falei das flores", de Geraldo Vandré, é convergente em seus propósitos com "Apesar de você". Nesse aspecto, elas são unanimidade, especialmente entre os estudiosos desse sombrio período da nossa história política. Mas, se por um lado, o texto poético de ambas tinha o mesmo objetivo, ou seja, contestar, lutar por meio das palavras contra a insensatez e a truculência que vinha da caserna, por outro lado, essa identidade cessava nesse momento. A canção de Vandré, intencionalmente, não trazia metáforas, metonímias ou qualquer outra figura de linguagem assentada na sutileza do discurso para as pessoas cultas. O que se tem nela é exatamente a objetividade da linha reta.

Qualquer cidadão que a ouvisse, entenderia o enfático e emocionado convite, aliás, pode-se falar de convocação, para fazer a revolução contra os militares que se apossaram do poder após o golpe de 31 de março de 1964. Transcrevo aqui o refrão, que não deixa dúvida dos propósitos da canção, seguido de uma estrofe que escolhi aleatoriamente. Sim, exatamente isso, aleatoriamente, porque qualquer uma delas mantém a clareza dos versos inconformados de Vandré.

Vejamos:
**Entrevista concedida ao jornalista José Rezende Júnior, do jornal Correio Braziliense, em 02 de setembro de 1999. 
Vem vamos embora

Que esperar não é saber

Quem sabe faz a hora

Não espera acontecer

Pelos campos há fome

Em grandes plantações

Pelas ruas marchando

Indecisos cordões

Ainda fazem da flor

Seu mais forte refrão

$\mathrm{E}$ acreditam nas flores

Vencendo o canhão

À parte o refrão que conclama a sociedade brasileira a fazer a revolução, Vandré nos mostra com refinada ironia a vida dramática e miserável do trabalhador rural dos latifúndios. Nos versos, "pelos campos há fome, / em grandes plantações” percebe-se a inominável absurdidade. O lavrador, o sertanejo, o boia-fria, enfim, o homem do campo, do meio rural que trabalha a terra para ser produtiva ao seu patrão, vê-se na situação indigna de passar fome, muito embora sua força de trabalho seja inteiramente dedicada a gerar a prosperidade das grandes plantações que, no final das contas, revertem-se em benefício do dono da terra. Mas apenas em benefício deste.

Nesse momento, é inevitável lembrar as obras de João Cabral de Melo Neto, Morte e vida Severina, e de Cândido Portinari, Os Retirantes. Ambas mostram as agruras da dura vida do homem nordestino abandonado à própria sorte que Vandré retoma em sua canção. Aqui, porém, há um aspecto a mais a se perceber em "Pra não dizer que não falei das flores". O autor não dirige sua conclamação especialmente ao homem do campo. A canção fala das pessoas "nas escolas, nas ruas, campos, construções", ou seja, é indistintamente, um apelo a todo o povo brasileiro. Esteja ele no meio rural, no interior ou no meio urbano-industrial.

Mas, como já disse anteriormente, escolhi essas duas canções por serem uma forte referência da época sobre o governo dos militares. No entanto, convém registrar que a repressão, a censura e as proibições, não se restringiram apenas às canções políticas. A vigilância imposta pelos militares à cultura brasileira foi além do fato essencialmente político. Os valores morais, os hábitos, os costumes, enfim, o próprio ethos cultural do cidadão brasileiro passaria a ser monitorado por uma espécie de moral social estabelecida pelo Estado a ser seguida por toda a sociedade. Apenas um ato autoritário a mais.

O cerceamento à liberdade era feito de forma truculenta e arbitrária. Todas as manifestações artísticas teriam, necessariamente, que passar pelo crivo censor do Estado. Alguns temas na música popular brasileira, por exemplo, estavam rigorosamente proibidos. Não por acaso, este período da nossa história ficou conhecido como os anos de chumbo da ditadura militar. Canções que falassem sobre prostituição, homossexualidade, hippies, racismo, exclusão social, drogas, sexo, histórias de amantes e adultérios, entre outros, estavam fadadas a mofar na gaveta dos censores. Seriam definitivamente proibidas. Segundo esses senhores, elas usurpavam os valores éticos e morais da sociedade brasileira. 
A chamada música brega, segmento importante, diria mesmo imprescindível, da nossa cultura lúdica e musical, foi especialmente prejudicada nessa ocasião. Perseguida. Este talvez seja o termo mais adequado. Quero, no entanto, esclarecer logo de início que essa perseguição se explica muito mais pelo despreparo dos censores, e muito menos pelas dissensões político-ideológicas que vivia o país. Não havia nada propriamente de político nessas canções.

As proibições às músicas de Odair José, o mais censurado entre os chamados cantores bregas, Waldick Soriano, Benito di Paula, Sidney Magal, Dom e Ravel, entre outros, são produtos das arbitrariedades, da incompetência e dos desmandos dos censores da caserna. A proibição a essas canções era essencialmente moral e objetivava defender, sob a ótica dos militares, os "valores morais" e os "bons costumes" de uma sociedade acuada pelo autoritarismo. Nessas circunstâncias, é claro que os temas acima citados seriam proibidos.

Para a censura militar eles eram considerados socialmente subversivos. Além da ação da força bruta contra todos os segmentos da cultura brasileira, devemos considerar ainda que a cultura lúdica, a cultura do entretenimento, tinha, como tem até hoje, grande espaço midiático. Isso incomodava muito os militares. Em certos momentos, eles investiam fortemente contra os media, especialmente a partir de 1968 com a brutal instituição do AI-5. Que se pense nas emissoras de rádio, como a Rádio Nove de Julho, Rádio Marconi, Rádio Cometa, entre outras. Todas elas foram definitivamente lacradas e todas estavam na cidade de São Paulo.

Assim, temas como drogas, exclusão social, homossexualismo, entre outros, eram vistos pelos senhores da caserna como algo inteiramente proibitivos. E aqui temos uma questão muito esclarecedora. Se de um lado, a censura proibia a veiculação de canções bregas, de outro lado, seus cantores e compositores nem imaginavam os verdadeiros motivos desse ato. Até porque, os próprios censores, em certas ocasiões, também não sabiam as razões da proibição. Apenas vetavam a obra sem explicações.

Odair José, por exemplo, não entendia e sempre estranhou ver algumas das suas canções censuradas. Ele jamais se manifestou ou fez protestos contra a opressão política e a censura dos militares. Suas canções, como de resto todo o segmento da chamada música brega, tinham um discurso ingênuo. Inofensivo mesmo. Em alguns casos, quase pueril. Tanto era assim, que não se tem registro de nenhuma prisão desses artistas, nenhum deles foi expulso do país, muito menos torturado.

Até hoje, cantores e compositores bregas daquela época, sabem e declaram que não lutaram contra a ditadura dos militares. Grande parte deles nem chegou a tomar conhecimento, por exemplo, da guerrilha urbana, dos sequestros, da luta armada, das torturas, dos desaparecidos, dos assassinatos, das prisões arbitrárias, enfim, do quadro sociopolítico desse período em nosso país. Faziam seu trabalho como se estivessem vivendo em pleno Estado de direito.

Para fazer justiça a esses profissionais, não podemos rotulá-los de alienados, como se fazia naquela época. Era um momento de intenso radicalismo político, que reverberava por todos os segmentos da sociedade. Não havia mediação político-ideológica. Quem não era declaradamente de esquerda e agisse como tal, estava sujeito, até mesmo por seus pares, a ser visto como radical de direita e, portanto, um alienado a favor do autoritarismo militar e do Estado burguês. 
Enfim, uma bobagem. Esse cidadão cairia em desgraça imediatamente; era obrigado a abandonar seu grupo social, porque passaria a rejeitá-lo ostensivamente. A recíproca era verdadeira. Quem não se declarasse notoriamente de direita, correria o sério risco de ser visto como inimigo do Estado. Nesse caso, as consequências eram bem sinistras. A pessoa passava a ser estreitamente vigiada e, em alguns casos, intensamente interrogada ou expulsa do país, torturada e até mesmo assassinada. Era assim. Pura insensatez de ambos os lados.

Em todo esse contexto, deve-se registrar, ainda, que havia um segmento da música popular brasileira que, embora não tivesse propriamente o estatuto de brega naquela época, era rejeitada pela intelligentsia da esquerda. Os motivos, claro, não eram estéticos e passavam pelas questões político-ideológicas, uma vez que o discurso poético, ao contrário das chamadas músicas de protesto, procurava reforçar o establishment imposto pela caserna. E aqui, por motivos óbvios, prevalecia o discurso consonante com o que desejavam os militares. Apologético, ufanista e, em alguns casos, até xenófobos. A divulgação dessas canções pelos mass media, como já se deduz, era muito maior do que qualquer outra forma de canção popular.

Quero lembrar a canção "Pra frente Brasil”, composição de Miguel Gustavo e Raul de Souza, feita em 1970, por ocasião da Copa do Mundo no México. Pela primeira vez, a televisão transmitia ao vivo jogos desse campeonato. Nessa ocasião, os patrocinadores do evento, Gillette, Esso e Souza Cruz, em parceria com a TV Globo, realizaram um concurso para escolher a melhor música sobre a Copa do Mundo. A vencedora foi transformada em uma espécie de hino que antecipava todos os jogos do Brasil. Após a vitória brasileira, de forma quase uníssona, os mass media, repetidas vezes tocavam "Pra frente Brasil" e conclamavam o povo brasileiro a sair às ruas para festejar mais uma vitória brasileira. Estávamos no auge da luta político-ideológica e o governo militar capitalizava de forma sutil as vitórias brasileiras em benefício da sua imagem.

Mas, certamente, o exemplo mais completo do ufanismo vivido nessa época está na canção "Eu te amo meu Brasil”, da autoria de Dom, integrante da dupla, Dom e Ravel. Gravada no início dos anos de 1970 pelo conjunto "Os Incríveis”, ídolo do Programa "Jovem Guarda", da TV Record, a canção fez grande sucesso junto à juventude brasileira e outros segmentos da sociedade. Para melhor ilustrar, reproduzo o refrão (que se repete nada menos que três vezes):

Eu te amo meu Brasil, eu te amo

Meu coração é verde, amarelo, branco, azul anil

Eu te amo meu Brasil, eu te amo

Ninguém segura a juventude do Brasil.

São muitas as canções desse período que seguem esse padrão discursivo. Esse era o estado comparativo, e deveria servir de modelo a todos os profissionais que não desejassem ver sua obra censurada. Apenas para lembrar, alguns compositores, já consagrados nessa época, chegaram a fazer canções que, mais tarde, foram criticadas pela chamada intelligentsia da esquerda. São os casos, por exemplo, de Ivan Lins, com sua canção "Meu país" e Jorge Ben, hoje conhecido por Jorge Benjor, com "País tropical". No tocante à música de Ivan Lins, entendo que há certo exagero quando a interpretam como apologética 
e ufanista. Trata-se muito mais de uma canção romântica, que funde valores do folclore brasileiro com a imagem da mulher amada. Isto está longe de ser apologético ou ufanista.

No caso de "País tropical", o que se percebe é um texto poético muito alegre, libertário e inteiramente descomprometido com qualquer conotação político-ideológica. É preciso fazer justiça a quem é inocente. Ivan Lins e Jorge Benjor jamais apoiaram a política dos militares e sempre estiveram coesos com os artistas que a rejeitavam. A canção mais criticada de Ivan Lins intitulada, "O amor é meu país”, nada tem de "adesista" como já se escreveu sobre ela. Por uma questão de espaço não posso analisá-la aqui, mas o leitor atento saberá interpretá-la.

Em outros termos, quero dizer o seguinte: não são apenas os exageros e as arbitrariedades da censura míope dos militares, que proibia coisas sem nem saber porquê estava procedendo daquele modo. Se isso era absolutamente repulsivo, não é aceitável também se fazer o chamado "patrulhamento ideológico", como aconteceu justamente com Ivan Lins e Elis Regina. Quando entrevistados pelo jornal O Pasquim foram severamente cobrados a declarar suas respectivas preferências político-ideológicas. Uma situação muito delicada, especialmente se considerarmos o contexto político que vivíamos.

\section{CONCLUSÃO}

Enfim, para a infelicidade da sociedade brasileira, esse foi o quadro político em nosso país durante 21 anos. Ao longo desse tempo, boa parte dos documentos sobre os acontecimentos políticos da época permaneceu confinada como segredo de Estado, em lugar incerto e não sabido, pelo menos por parte do grande público. Apenas a partir dos governos de Fernando Henrique Cardoso e Lula é que tomamos conhecimento de alguns documentos que se tornaram públicos para os pesquisadores, estudiosos e para toda sociedade brasileira.

A Comissão da Verdade instalada pela presidenta Dilma Roussef, em 16 de maio de 2012, certamente trará à luz do conhecimento público, muitos outros fatos e elementos novos ainda desconhecidos desse sombrio período político do nosso país. Restará, portanto, aos pesquisadores e estudiosos, interpretar e reinterpretar os fatos novos até então confinados nos arquivos proibidos à pesquisa e ao conhecimento público.

Para terminar este pequeno ensaio, quero fazer das palavras da nossa presidenta, as minhas palavras. Quando da instalação da Comissão da Verdade ela disse em seu discurso: "Ao instalar a Comissão da Verdade não nos move o revanchismo, o ódio ou o desejo de reescrever a história de uma forma diferente do que aconteceu, mas nos move a necessidade imperiosa de conhecê-la em sua plenitude, sem ocultamentos, sem camuflagens, sem vetos e sem proibições”. Apenas para manter fidelidade ao texto, mantive a palavra ocultamentos, mas o correto é ocultações. Nossa presidenta termina seu discurso assim: “[...] a força pode esconder a verdade, a tirania pode impedi-la de circular livremente, o medo pode adiá-la, mas o tempo acaba por trazer a luz. Hoje esse tempo chegou”***.

Toda a sociedade brasileira precisa realmente acreditar no que disse nossa presidenta. $\mathrm{O}$ ódio e o revanchismo não contribuirão em nada. $\mathrm{O}$ acirramento de situações políticas não resolvidas até hoje, especialmente no plano ideológico, devem ficar sob a responsabilidade do Estado democrático que vivemos.

\footnotetext{
***Trecho do discurso da presidenta Dilma Rousseff, quando da instalação da "Comissão da Verdade", em 16 de maio de 2012, no Congresso Nacional.
} 
Não sabemos a quais resultados chegarão a Comissão da Verdade. Estamos conscientes, isto sim, da sua importância para ajudar a elucidar muitos fatos políticos sombrios, obscuros mesmo, que tanto mal causou às pessoas dispostas a lutar sem limites pela redemocratização do nosso país.

Quase que diariamente, os grandes veículos de comunicação nos revelam os resultados a que essa Comissão tem chegado, especialmente no tocante aos acordos entre os militares do Brasil, Uruguai, Argentina e Chile. A troca de presos políticos, de informações, de experiências sobre repressão, enfim, todos aqueles elementos postos em prática pela fatídica "Operação Condor".

Que se pense nos torturados, naqueles cidadãos que sobreviveram a essa inominável barbárie, nas pessoas assassinadas e naquelas que perderam definitivamente sua sanidade mental e hoje vivem compelidos e confinados à profunda reclusão. A Comissão da Verdade pode chegar aos fatos reais de alguns episódios ainda obscuros. Apenas isso.

Resta saber se isso responde às expectativas da sociedade. A Comissão não tem poder para julgar e indicar penas por crimes políticos hediondos como a tortura e a morte, muito embora haja um respeitável grupo de estudiosos do direito penal que considere esse tipo de crime imprescritível. Nessas condições, se a justiça brasileira não concordar com esta última tese, a descoberta de novos fatos históricos terá mero efeito de uma pesquisa de alto nível para se chegar à verdade. Assim, a necessidade imperiosa de se conhecer a verdade sem ocultações e em sua plenitude, muito provavelmente um dia será alcançada. A sociedade brasileira anseia por esse momento, muito embora diversos segmentos, como a nossa juventude, por exemplo, esperem muito mais.

\section{REFERÊNCIAS}

ARAÚJO, P.C. de Eu não sou cachorro não. Rio de Janeiro: Record, 2003

CALDAS, W. A cultura político-musical brasileira. São Paulo: Musa, 2005. COUTO, R.C. História indiscreta da ditadura e da abertura no Brasil: 1964-1985.

Rio de Janeiro: Record, 1998.

SILVA, D. da Nos bastidores da censura. São Paulo: Clube do livro, 1989. TELES, J. (Org.) Reparação ou impunidade? São Paulo: Humanitas, 2001. VALLE, M. R. 1968 - o diálogo é a violência. Campinas: Unicamp, 2008.

WALDENYR CALDAS professor titular da Escola de Comunicações e Artes da Universidade de São Paulo (ECA-USP)-e-mail:waldenyr@usp.br 